\title{
PODÍL ČESKÝCH CHEMIKU゚ NA ROZVOJI POZITRONOVÉ EMISNÍ TOMOGRAFIE
}

8: 1 - 200, 2006

ISSN 1212-4117

\section{Jiří Patočka}

Jihočeská univerzita v Českých Budějovicích, Zdravotně sociální fakulta, katedra radiologie a toxikologie

Pozitronová emisní tomografie (PET) je jednou z nejmodernějších metod diagnostického zobrazení v nukleární medicíně a nejdynamičtěji se rozvíjející vyšetřovací metodou posledních let (Bělohlávek a Fencl, 2004). Je založena na použití radioizotopů emitujících pozitrony. Základním principem PET je detekce dvou fotonů gama, které vznikají ve tkáni při anihilaci dvou antičástic, pozitronu a elektronu. Oba fotony vznikají ve stejný okamžik, mají stejnou energii o velikosti $511 \mathrm{KeV}$ a emitují se v opačných směrech, tedy v úhlu 180 stupñu do okolního prostoru. Aby byly zachyceny a zaznamenány, musí dopadnout na dva protilehlé detektory, které jsou zapojeny tak, aby zaznamenaly jejich současný dopad (koincidenční zapojenî). Tím je zaručeno, že přístroj bude detekovat pouze fotony uvolnění při anihilaci. Data jsou uchovávána v paměti počítače a ten z nich vytvoří obraz prostorového rozložení podaného radiofarmaka.

Protože radioizotopy emitující pozitrony mají relativně krátký poločas, připravují se uměle, většinou přímo na oddělení, pomocí cyklotronu. Jde především o radionuklidy ${ }^{11} \mathrm{C}$ (poločas 20 minut), ${ }^{13} \mathrm{~N}$ (10 minut), ${ }^{15} \mathrm{O}$ (2 minuty) a zejména ${ }^{18} \mathrm{~F}$ (110 minut). Nejdůležitějši a nejpoužívanější radiofarmakum v PET je ${ }^{18}$ F-fluorodeoxyglukóza (FDG). To se využívá pro zobrazení oblastí s vysokým metabolickým obratem glukózy, takže nachází největší využití zejména $\mathrm{v}$ onkologii, kardiologii a neurologii. Protože nádorová buňka má při svém rychlém růstu velkou spotřebu glukózy, vstupuje do ní FDG v mnohem větší míre než do buňky zdravé. Nádorová buňka je tak označena tímto radiofarmakem a pomocí PET ji lze snadno identifikovat (Picard, 2000). Tímto způsobem lze označit i jiné buňky s rozdílným metabolismem glukózy. Proto se PET použivá ke zjišt’ování viability myokardu při ischemické chorobě srdeční (Ghesani et al., 2005) nebo v neurologii ke zjišt'ování aktivace určitých mozkových struktur při různých činnostech nebo neurodegenerativních chorobách (Herholz a Heiss, 2004).

Mezníkem ve vývoji PET byl objev 2-deoxy-2
-fluor-D-glukózy v roce 1968, která byla v roce 1978 označena radioizotopem ${ }^{18} \mathrm{~F}$ s poločasem rozpadu 110 minut. Tato látka odstartovala bouřlivý rozvoj PET, který od té doby téměř exponenciálně narůstá (http://www.csnm.cz). Jen málo lidí však ví, že prototyp této molekuly a syntéza substance byla provedena na Prírodovědecké fakultě Univerzity Karlovy v Praze českými chemiky, J. Pacákem, Z. Točíkem a M. Černým. Článek o syntéze FDG publikovali v roce 1969 (Pacák et al., 1969). Když byli o několik let později požádáni Dr. Sidneym D. Drellem z Kalifornské univerzity v La Jolle o prodej této látky, vůbec netušili, jaký by mohla mít pro někoho význam. Celou historii popisují prof. Pacák a Dr. Černý ve vzpomínkovém článku v Chemických listech (Pacák a Černý, 2002a) (viz též Pacák a Černý, 2002b). Teprve další pokroky ve vývoji této metody ukázaly, jak významným př́nosem pro rozvoj PET byla právě príprava 2-deoxy-2-fluor-D-glukózy. Ne nadarmo je dnes FDG považována za molekulu století (http://archiv.neviditelnypes.zpravy.cz/veda/ clanky/27692_0_0_0.html).

\section{LITERATURA}

BĚLOHLÁVEK, O., FENCL, P.: Hybridní zobrazování výpočetní a pozitronovou emisní tomografií. Inter. Med. Praxi 2: 61-63. http://www.internimedicina.cz/pdf/ impp/2004/02/02.pdf, 2004.

PICARD, J.D.: Positron emission tomography in tumor patology. Bull, Acad, Natl, Med. 184: 1023-1029, 2000. GHESANI, M., DEPUEY, E.G., ROZANSKI, A.: Role of F -18 FDG positron emission tomography (PET) in the assessment of myocardial viability. Echocardiography 22: 165$177,2005$.

HERHOLZ, K., HEISS, W.D.: Positron emission tomography in clinical neurology. Mol. Imaging Biol. 6: 239-269, 2004.

PACÁK, J., TOČÍK, Z., ČERNÝ, M. 1969. Synthesis of 2Deoxy-2-fluoro-D-glucose, Chem. Listy 73: 77.

PACÁK, J., ČERNÝ, M.: Deoxyfluorglukosa, mezník ve vývoji pozitronové emisní tomografie (historie jednoho výzkumu) Chem listy 96: 704-707, 2002a.

PACÁK, J., ČERNÝ, M.: History of the first synthesis of 2deoxy-2-fluoro-D-glucose the unlabeled forerunner of 2deoxy-2-[18F]fluoro-D-glucose. Mol. Imaging Biol. 4: 352$354,2002 b$. 